\title{
STRATEGI RIAU TELEVISI (RIAU TV) MENGHADAPI PERSAINGAN DENGAN TV NASIONAL UNTUK TETAP EKSIS SEBAGAI TV LOKAL
}

\author{
${ }^{1}$ Peramasdino Syafri. ${ }^{2}$ Sri Tunggul Pannindriya \\ ${ }^{12}$ London School of Public Relations - Jakarta (Post Graduate Programme) \\ E-mail: ${ }^{1}$ peramasdino@gmail.com. ${ }^{2}$ tunggul.p@1spr.edu
}

\begin{abstract}
Riau Televisi (Riau TV) is the first local television station in the Riau region located in the city of Pekanbaru. As a local television station in Riau, Riau TV clearly has to compete with national television stations, in fighting for viewers in the Riau region. In order to be able to compete with broadcasts from national television, as local television, Riau TV has a special strategy in broadcasting programs, including for marketing targets. The purpose of this research is to find out the strategy carried out by Riau TV, in facing competition with National TV and maintaining its existence as a local TV in Riau. The theory underlying the research is the theory of Media Ecology by Dimmick and Rothenbuhler. In media ecology theory, Dimmick and Rotherbuhler revealed that media needs life-supporting sources, namely types of content, types of audience. and capital. This study uses descriptive qualitative methods and data collection through interviews with Riau TV directors and management, observation and document collection for research purposes. The paradigm used in this study is constructivism. The main focus in this research is to find out what strategies Riau TV has taken to be able to compete with national TV in maintaining its existence. The results of this study concluded, to be able to compete with National TV, Riau TV has a strategy, among others; (1) Strategies for local content TV programs to capture the local audience market, (2) Strategies to expand cooperation networks with local governments, (3) Strategies utilizing internet technology and (4) Strategies to hold off air activities and special moments.
\end{abstract}

Keywords: TV Strategy, TV Competition, Local Content, Existence, Local TV

\section{A. PENDAHULUAN}

Penetapan desentralisasi penyiaran yang diatur dalam Undang- Undang No. 32 tahun 2002 tentang Penyiaran, telah membuat dunia penyiaran di Indonesia banyak mengalami perubahan. Undangundang yang menjadi payung hukum resmi terhadap eksistensi lembaga penyiaran lokal, baik swasta, komunitas, dan publik ini, secara langsung membuka perizinan atas berdirinya televisi-televisi lokal daerah di Indonesia. Hal inilah yang memicu lahir dan berkembangnya televisi lokal di berbagai daerah di Indonesia (Rinowati, 2011, p. 3).

Berkenaan dengan Otonomi Daerah dan Desentralisasi, dengan adanya UndangUndang No. 32 tahun 2002 tentang Penyiaran, keberadaan TV lokal mendapatkan restunya. TV lokal lahir berkat adanya gairah otonomi daerah. TV lokal bisa menjadi media lokal yang akan memfasilitasi masyarakat di daerah, untuk mendapat informasi dan hiburan yang berkonten lokal. Kondisi ini menjadikan TV lokal memiliki prospek cerah bagi kemajuan dunia pertelevisian, khususnya media elektronik di Indonesia.

Sebagaimana kedudukannya sebagai media daerah, maka dalam penyajian dan kemasannya, TV lokal cenderung menampilkan konten lokal, kearifan lokal dan mengedepankan permasalahan daerah, baik dari isu yang diangkat maupun dari bahasa yang digunakan. Selain penggunaan bahasa daerah, konten pemberitaan termasuk sejumlah program acaranya, TV lokal lebih fokus membahas permasalahan lokal, tempat TV itu menyiarkan programnya.

Namun sayangnya perkembangan kuantitas TV lokal di Indonesia, tidak diikuti dengan perkembangan kualitasnya. Tidak sedikit televisi lokal saat ini yang masih jauh dari harapan (Haryati, 2013, p. 5). Meskipun dari waktu ke waktu, pertumbuhan televisi lokal terus bertambah, semangat membangun lokalitas siaran itu tak diimbangi daya untuk bertahan. Beberapa stasiun televisi lokal dalam perjalanannya tidak mampu bersaing dan mempertahankan eksistensinya, karena beratnya persaingan dalam industri penyiaran. Televisi-televisi yang bersiaran secara nasional menjadi tantangan terberat bagi TV lokal, untuk bisa menggaet pemirsa daerah dan memperoleh iklan.

Terbatasnya investasi dan masih lemahnya daya saing terhadap TV nasional, 
menjadi kendala bagi TV lokal dalam bersaing dengan TV nasional, yang mengakibatkan TV lokal kesulitan mengembangkan diri. Popularitas TV lokal di tengah masyarakat yang kalah jauh dibanding TV nasional juga menjadi faktor bagi minimnya sponsor dan investasi pengiklan untuk ikut menghidupi TV lokal.

Apalagi belakangan TV nasional juga membuat jaringan TV lokal di daerah, melalui Sistem Stasiun Jaringan (SSJ), khususnya daerah-daerah yang dianggap strategis dan memiliki jumlah pemirsa yang cukup banyak. Hal ini untuk memenuhi ketentuan peraturan dan Undang-undang Penyiaran, dimana setiap TV nasional harus bisa menayangkan muatan lokal dengan persentase minimal 10 persen.

Selain itu, seiring dengan perkembangan ilmu dan teknologi, khususnya di bidang pertelevisian, mau tidak mau TV lokal juga harus bisa menguasai multi media dan juga memprioritaskan konvergensi media. Konvergensi ini merupakan penyiaran yang tidak hanya berbasis internet tetapi juga berbasis IT platform lain, seperti misalnya di smartphone, yang menyesuaikan berbagai keinginan masyarakat untuk menerima siaran TV melalui jaringan TV streaming.

Dari permasalahan di atas, menjadi menarik bagi peneliti untuk mengkaji bagaimana strategi yang dilakukan oleh sebuah TV lokal untuk bersaing dengan TV Nasional dan bisa bertahan. Dalam penelitian ini peneliti memilih Riau TV sebagai objek penelitian, karena berdasarkan pengamatan yang peneliti lakukan, Riau TV mampu menjalankan peran yang cukup baik sebagai TV lokal di wilayah Riau, dengan terus konsisten memproduksi dan menayangkan program-programnya yang sebagian besar merupakan konten lokal.

Riau Televisi (Riau TV) merupakan stasiun televisi lokal pertama di wilayah Riau yang berlokasi di kota Pekanbaru. Riau TV tergabung didalam Stasiun televisi berjaringan JPMC (Jawa Pos Media Corporation), dan mulai mengudara pada tanggal 20 Mei 2001, dengan coverage area-

Eko dan Bisnis (Riau Economics and Business Reviewe) Volume 10, Nomor 3, 27 September 2019 nya di 12 kabupaten/kota di Propinsi Riau dengan jumlah penduduk 6,717 juta jiwa (data BPS Propinsi Riau tahun 2018). Penduduk provinsi Riau terdiri dari bermacam-macam suku bangsa, terdiri dari Jawa (25,05\%), Minangkabau (11,26\%), Batak $(7,31 \%)$, Banjar $(3,78 \%)$, Tiong Hoa $(3,72 \%)$, dan Bugis $(2,27 \%)$. Suku Melayu merupakan masyarakat terbesar dengan komposisi $37,74 \%$ dari seluruh penduduk Riau. Luas wilayah provinsi Riau adalah 87.023,66 km2, yang membentang dari lereng bukit barisan hingga Selat Malaka. Saat ini Riau TV memiliki jam siaran perharinya selama $18 \mathrm{jam}$, yang dimulai pada pukul 06.00 WIB sampai 24.00 WIB.

Sebagai sebuah stasiun televisi lokal di Riau, Riau TV jelas harus bersaing dengan stasiun televisi nasional, dalam memperebutkan jumlah penonton atau pemirsa dan segmentasi pasar maupun iklan di wilayah Riau. Televisi nasional jauh lebih unggul dalam hal program siaran maupun program pemberitaan yang ditayangkan, termasuk juga unggul dalam teknologi jaringan TV dengan kualitas visual yang bagus dalam penayangannya (Wahyudi, 2013, p. 8).

Namun Riau TV masih tetap bisa mempertahankan eksistensinya sebagai TV lokal yang telah beroperasi selama 18 tahun. Untuk itu agar bisa bersaing dengan TV nasional, sebagai televisi lokal Riau TV mempunyai strategi khusus dalam penayangan program acara, termasuk untuk sasaran pemasarannya.

\section{Teori Ekologi Media}

Ekologi berasal dari bahasa Yunani, terdiri kata oikos atau tempat tinggal, dan logos yang berarti ilmu. Ekologi diartikan sebagai ilmu yang mempelajari hubungan timbal balik antara makhluk hidup dengan lingkungannya (Resosoedarmo. 1990. p. 1). Dari pengertian ekologi tersebut kemudian diperluas oleh Hawley dalam Sills (1986. p. 328) sebagai ilmu yang mempelajari tentang bagaimana cara makhluk hidup atau suatu organisme hidup dalam suatu lingkungan hidup dalam lingkungan

P.ISSN: 1410-7988 E.ISSN: 2614-123X 
tertentu. Dari dua pengertian sebelumnya disimpulkan bahwa ekologi adalah ilmu yang mempelajari bagaimana cara makhluk hidup mempertahankan hidupnya di lingkungan dimana mereka tinggal. (dalam Prasetiya, 2011, p. 29).

Ekologi kemudian berkembang seiring dengan perkembangan ilmu pengetahuan. Kemudian muncullah ekologi media yang memiliki inti yang sama yakni bagaimana hubungan timbal balik antara media dan lingkungannya agar mampu mempertahankan hidupnya. Sumber alam menurut Dimmick dan Rohtenbuhler (1984, p. 293) diartikan sebagai : “... the elements of the environments that are required for industries in our society, a minimal set of resources would include content, audience, capital" yaitu elemen-elemen yang berasal dari lingkungan sekitar yang dibutuhkan oleh industri sebagai penunjang hidupnya, sumbernya antara lain modal, isi, audiens. (dalam Prasetiya, 2011, p. 5).

Ekologi juga dapat digunakan untuk menjelaskan adanya keterkaitan antara makhluk hidup dengan lingkungannya. Dimanapun berada suatu makhluk hidup tidak akan dapat hidup mandiri, karena memiliki ketergantungan dengan makhluk hidup lain. Begitu juga dengan media, yang didalamnya terdapat tiga penunjang hidup, dimana ketiganya memiliki hubungan dan saling terkait untuk saling melengkapi (Sari, 2011, p. 10).

Dimmick dan Rohtenbuhler (1984) mencoba menganalogikan fenomena kompetisi antar industri media sebagai suatu proses ekologis. Dalam pandangannya kompetisi media dapat digambarkan seperti makhluk-makhluk hidup yang harus mempertahankan hidupnya dalam suatu lingkungan (pasar). Bagaimana ia bertahan adalah bagaimana makhluk media tersebut mampu mencari - mendapatkan dan merebut sumber makanan yang tersedia dalam lingkungan tersebut. Persoalannya adalah jika sumber makanan yang ada di lingkungan tersebut terbatas - sementara makhluk hidup yang menggantungkan dirinya kepada sumber tersebut semakin banyak maka faktor

Eko dan Bisnis (Riau Economics and Business Reviewe) Volume 10, Nomor 3, 27 September 2019 kompetisi tidak terelakkan (dalam Herawati \& Budi, S. 2007, p. 113)

Dimmick dan Rohtenbuhler mengungkapkan bahwa untuk mempertahankan kelangsungan hidupnya media memerlukan sumber penunjang hidup. Pada dasarnya, ada tiga sumber penunjang hidup media yang utama yaitu: types of content (jenis isi media), types of audien (jenis khalayak sasaran), dan capital/ (modal) (dalam Kriyantono. 2007. p. 272). Dimmick dan Rohtenbuhler (dalam Haryati. 2011. p. 4) mengungkapkan bahwa ketiga sumber penghidupan media tersebut, pertama adalah types of content, yang menunjukkan aspek program dan atau jenis isi media. Variasi program, jenis program, dan banyaknya program. Content merupakan deskripsi isi dari media yang bersangkutan, hal tersebut dapat dilihat dari berbagai rubrikasi/ program acara yang ada. (Sari, Pingkan. E \& Pramonojati, Twin. A. 2019. p. 1864 - 1865)

Alan B. Albarran dalam Handbook of Media Studies (2004, p. 299) mengatakan bahwa konten media adalah produk-produk yang diciptakan oleh perusahaan media, konten media berbentuk program televisi (dalam media televisi), film, suara dan rekaman video, dan cetak (misalnya, buku, majalah, koran). Konten media secara luas diklasifikasikan ke dalam kategori informasi (terkait konten berita) dan hiburan (drama, komedi, action, musik, games, dan lain-lain). Konten media merupakan produk yang dapat secara berulang digunakan dan dipasarkan kepada audien dan pengiklan. Kedua, types of audience, yang menunjukkan jenis khalayak sasaran atau target audien, jenispendengar (dari segmentasi geografis, demografis, psikografis). Ketiga, capital, yang meliputi struktur permodalan dan pemasukan iklan. Faktor capital (modal), yang mencakup modal finansial, dana pemasukan iklan, sumber daya manusia, sarana teknologi dan fasilitas lainnya.

Ketiga sumber penunjang tersebut merupakan tiga tiang utama yang menjadi penyangga sekaligus sumber "makanan"

P.ISSN: 1410-7988 E.ISSN: 2614-123X 
bagi media agar dapat survive dan mengembangkan dirinya dalam situasi kompetisi yang ketat. Dan ketiga sumber ini yang berusaha untuk diperebutkan oleh berbagai media agar bertahan. (Kriyantono, 2007, p. 272).

\section{Strategi Program TV}

Dalam industri penyiaran, strategi digunakan dalam berkompetisi dengan stasiun penyiaran lain dalam rangka memperebutkan audien. Stasiun penyiaran selalu merencanakan programnya secara strategis, yaitu merancang acara sebaik mungkin, sehingga tetap menarik dan menjaga ketertarikan pemirsanya (Djamal, 2011, p. 135). Salah satunya dengan cara membuat program yang dekat dengan kehidupan mereka sehari-hari dan sesuai dengan keinginan mereka.

Departemen program dan produksi stasiun penyiaran memiliki kedudukan yang sangat strategis dalam menunjang keberhasilan stasiun penyiaran. Morissan dalam bukunya "Manajenemen Media Penyiaran", mengungkapkan bahwa strategi program ditinjau dari aspek manajemen atau yang sering disebut manajemen strategis (management strategic) terdiri dari (2008, p. 231):

\section{Perencanaan program}

Menurut Morissan pada stasiun televisi, perencanaan program diarahkan pada produksi program apa yang akan diproduksi dan penjadwalan program untuk menarik sebanyak mungkin audien yang tersedia pada waktu tertentu. Perencanaan program mencakup rencana jangka pendek, menengah, dan jangka panjang bagi stasiun penyiaran untuk mendapatkan tujuan program dan tujuan keuangannya. Perencanaan suatu program televisi diarahkan pada program yang akan diproduksi, pemilihan program yang akan dibeli (akuisisi), dan penjadwalan program untuk menarik sebanyak mungkin audien yang tersedia pada waktu tertentu. Pengelola stasiun televisi harus mengarahkan programnya kepada segmen audien tertentu pada waktu siaran tertentu. Pada stasiun

Eko dan Bisnis (Riau Economics and Business Reviewe) Volume 10, Nomor 3, 27 September 2019 afiliasi lokal (lokal berjaringan), perencanaan program juga harus memutuskan program televisi jaringan yang mana yang akan disiarkan, program apa yang akan ditolak atau ditunda, dan seterusnya.

Perencanaan dan pemilihan program merupakan keputusan bersama divisi program dan divisi pemasaran. Kedua divisi ini harus bahu membahu menyusun strategi program terbaik. Ada beberapa hal yang dibahas dalam perencanaan program, yang dikenal dengan 'bauran program' (programming mix) yang terdiri atas ; (1). Produk program (product), bahwa program merupakan suatu produk yang ditawarkan kepada audien, mencakup nama program dan kemasan program; (2). Harga program (price), mencakup biaya produksi program dan biaya yang akan dikenakan kepada pemasang iklan (tarif iklan) pada program bersangkutan jika ditayangkan; (3). Distribusi program (place), yaitu proses pengiriman program dari transmisi hingga diterima audien melalui pesawat TV dan radio; (4) Promosi program (promotion), yaitu proses bagaimana memberitahu audien mengenai adanya suatu program sehingga mereka tertarik untuk menonton atau mendengarkannya.

2. Produksi dan pembelian program

Manajer program bertanggung jawab melaksanakan rencana program yang sudah ditetapkan dengan cara memproduksi sendiri program atau mendapatkannya dari sumber lain yang dikenal dengan akuisisi program (membeli program).

Dalam memproduksi atau membuat program kata kuncinya adalah ide atau gagasan. Sedangkan jika memberi program, dilihat siapa yang memproduksi program. Pada dasarnya, stasiun televisi menginginkan program diproduksi sendiri dengan alasan yaitu, lebih menghemat pengeluaran.

3. Eksekusi atau penayangan program

Eksekusi program mencakup kegiatan menayangkan program sesuai rencana yang sudah ditetapkan. Manajer program harus melakukan koordinasi dengan bagian traffic

P.ISSN: 1410-7988 E.ISSN: 2614-123X 
dalam menentukan jadwal penayangan, serta berkonsultasi dengan manajer promosi dalam mempersiapkan promo bagi program tersebut. Strategi penayangan program yang baik ditentukan bagaimana menata atau menyusun berbagai program yang akan ditayangkan. Bagian program menganalisis dan memilah-milah setiap bagian waktu siaran untuk mendapatkan berbagai audien yang diinginkan, karena jam yang berbeda akan mendapatkan audien yang berbeda pula.

4. Pengawasan dan evaluasi program

Proses pengawasan dan evaluasi, menentukan sejauh mana rencana dan tujuan telah dicapai atau direalisasikan oleh stasiun penyiaran, departemen, dan karyawan. Kegiatan evaluasi secara periodik terhadap masing-masing individu dan departemen memungkinkan manajer umum untuk membandingkan kinerja sebenarnya dengan kinerja yang direncanakan.Pengawasan dilakukan dengan melihat hasil kerja dan kinerja yang dapat diukur, seperti melihat jumlah dan komposisi audien yang menonton program yang bersangkutan, serta tingkat penjualan iklan stasiun penyiaran (Morissan, 2009, p. 315)

Peter Pringle mengungkapkan, dalam pengawasan program, manajer program harus melakukan hal-hal sebagai berikut : (1). mempersiapkan standar program stasiun penyiaran, (2). mengawasi isi program agar sesuai standar dan aturan perundangan yang berlaku, (3) memelihara catatan program yang disiarkan, (4) mengarahkan dan mengawasi kegiatan staff departemen program, (5) memastikan kepatuhan stasiun terhadap kontrak yang sudah dibuat, (6) memastikan biaya program tidak melebihi jumlah anggaran yang telah dianggarkan.

\section{Televisi Lokal}

Televisi lokal menurut Sudibyo (2004, p.105) merupakan stasiun penyiaran dengan wilayah siaran terkecil yang mencakup satu wilayah kota atau kabupaten. Definisi oleh Sudibyo diperkuat oleh Undang - Undang No. 32 Tahun 2002 tentang Penyiaran, dalam pasal 31 ayat 5 yang menyatakan bahwa, Stasiun penyiaran lokal

Eko dan Bisnis (Riau Economics and Business Reviewe) Volume 10, Nomor 3, 27 September 2019 dapat didirikan di lokasi tertentu dalam wilayah negara Republik Indonesia dengan wilayah jangkauan siaran terbatas pada lokasi tersebut.

Dengan berlakunya UU No. 32 Tahun 2002 tentang Penyiaran, izin penyiaran siaran televisi lokal melalui antena UHF/VHF. UU tersebut berlaku untuk stasiun televisi lokal yang menyelenggarakan siaran lokal. Sehingga dengan adanya UU tersebut, banyak bermunculan siaran televisi lokal yang dapat dinikmati oleh masyarakat di daerah tersebut, secara gratis.

Dilihat dari perspektif teori Berger dan Luckman, dalam kontruksi realitas penyiaran pada televisi lokal, dibagi tiga yaitu objective reality, symbolic reality dan subjective reality. Sementara proses konstruksinya, berlangsung dalam suatu proses dengan tiga momen, antara lain; simultan, eksternalisasi, objektifikasi, dan internalisasi. (Hidayat, 2003).

Sebagaimana media lainnya, televisi lokal juga memiliki fungsi, tidak jauh beda dengan media massa lainnya, fungsi media televisi lokal adalah untuk memberi informasi, mendidik, mempersuasi, menyenangkan, memuaskan, dan sebagai hiburan (McQuail, 1991, p. 70-73).

Perbedaan TV lokal dengan TV swasta yang bersiaran nasional, berkaitan dengan kandungan isi berita dan programnya. TV lokal beritanya lebih mengacu dan menyesuaikan diri pada kebutuhan dan kepentingan masyarakat setempat dimana media massa tersebut dikelola. Media massa lokal mempunyai ciri-ciri sebagai berikut (Sucipto, 1998, p. 5) :

1. Media massa itu dikelola oleh organisasi yang berasal dari masyarakat setempat.

2. Isi media massa lokal mengacu dan menyesuaikan diri kepada kebutuhan dan kepentingan masyarakat setempat.

3. Isi media massa sangat mementingkan berita-berita tentang berbagai peristiwa, kejadian, masalah, dan personalia atau 
tokoh-tokoh pelaku masyarakat setempat.

4. Masyarakat media massa lokal terbatas pada masyarakat yang sewilayah dengan tempat kedudukan media massa itu.

5. Khalayak TV lokal umumnya kurang bervariasi dalam struktur ataupun diferensiasi sosial bila dibandingkan dengan khalayak media massa nasional.

Jadi, kekuatan televisi lokal sebenarnya terletak pada bagaimana melalui segmentasi dan programnya, televisi lokal dapat menciptakan identitas lokal bagi pemirsanya, menciptakan tayangan-tayangan acara yang menjadi kebutuhan dan minat masyarakat setempat. (Haryati, 2013, p. 14).

Dalam rangka mewujudkan keberagaman isi siaran lokal, pemerintah menetapkan kebijakan Sistem Stasiun Jaringan (SSJ) yang mengatur mengenai sistem penyiaran televisi swasta, yang termuat dalam Peraturan Menteri Kominfo nomor 43 tahun 2009. Hal esensial yang diatur oleh peraturan menteri ini adalah (1) Lingkup lembaga penyiaran swasta merupakan stasiun penyiaran lokal; (2) Dalam menjangkau wilayah yang lebih luas, lembaga penyiaran swasta dapat membentuk sistem stasiun jaringan. Stasiun televisi nasional disebut dengan stasiun induk dan harus memiliki stasiun anggota di tiap daerah (Pasal 2 Peraturan Menteri No. 43 tahun 2009).

Dalam Kebijakan Sistem Stasiun Jaringan (SSJ), tidak ada lagi istilah televisi nasional, semua stasiun televisi swasta merupakan stasiun televisi lokal. Kebijakan ini juga mengharuskan stasiun-stasiun televisi swasta yang hendak bersiaran secara nasional untuk bekerjasama dengan stasiun televisi daerah (lokal) untuk menyalurkan siaran mereka di daerah tersebut. Sehingga, stasiun televisi lokal daerah tersebut secara langsung juga akan mendapatkan pembagian keuntungan dari setiap bentuk tayangan TV induk yang disiarkannya.

Selain itu kebijakan Sistem Stasiun Jaringan (SSJ) ini juga membatasi volume program TV swasta induk yang disiarkan oleh TV lokal yakni, hanya sebesar

Eko dan Bisnis (Riau Economics and Business Reviewe) Volume 10, Nomor 3, 27 September 2019
$50 \%$, sedangkan $50 \%$ lagi adalah program dengan konten lokal. Namun, karena kebijakan ini masih dalam perkembangan, maka secara berangsur-angsur penayangan volume siarannya dimulai dari $10 \%$ program konten lokal dan $90 \%$ program dari TV nasional (TV induk), hingga pada akhirnya nanti setiap lembaga penyiaran televisi lokal harus menyiarkan batas minimum isi siarannya $50 \%$ berisikan muatan lokal dan 50\% muatan nasional.

\section{METODE}

Metode yang dilakukan dalam penelitian ini adalah metode kualitatif. Metode kualitatif adalah suatu metode penelitian yang mengungkap situasi sosial tertentu dengan mendeskripsikan kenyataan secara benar, dibentuk oleh kata-kata berdasarkan tekhnik pengumpulan dan analisis data yang relevan yang diperoleh dari situasi yang alamiah (Satori, 2009, p. 25). Menurut Kriyantono (2007, p. 56), riset kualitatif bertujuan untuk menjelaskan fenomena sedalam-dalamnya melalui pengumpulan data sedalam-dalamnya. Metode kualitatif menjadikan peneliti sebagai instrumen utama penelitian dimana penarikan kesimpulan yang dilakukan berdasarkan hasil wawancara peneliti dengan dokumen pendukung lainnya.

Dalam penelitian ini peneliti memfokuskan untuk mengungkap strategi yang dilakukan Riau TV dalam menghadapi persaingan dengan TV Nasional, dimana dalam hal program siaran maupun keunggulan teknologi pertelevisian, TV Nasional jauh lebih unggul disbanding TV lokal, termasuk Riau TV. Selain itu penelitian ini juga untuk mengungkap bagaimana Riau TV bisa tetap eksis sebagai TV lokal di wilayan Riau, dan mampu bertahan dalam 18 tahun terakhir sejak pertama mengudara di tahun 2001 silam. Seterusnya penelitian ini juga untuk mengungkap kendala-kendala yang dihadapi Riau TV dalam menjalan strateginya untuk bersaingan dengan TV Nasional sekaligus bisa tetap eksis sebagai TV lokal di wilayah Riau.

P.ISSN: 1410-7988 E.ISSN: 2614-123X 
Adapun jenis penelitian yang digunakan adalah analisis deskriptif. Menurut Moloeng (1997: 6) analisis deskriptif diartikan dengan melukiskan variabel demi variabel, satu demi satu. Jenis penelitian analisis deskriptif ini bertujuan membuat deksripsi secara sistematis, faktual, dan akurat tentang fakta-fakta dan sifat-sifat populasi atau objek tertentu.

Pada penelitian ini, peneliti mendeskripsikan bagaimana strategi yang dilakukan Riau TV dalam mempertahankan eksistensinya di tengah persaingan media, khususnya TV Nasional, termasuk kendalakendala yang dihadapi.

\section{Paradigma Penelitian}

Paradigma penelitian menurut Guba \& Lincoln (dalam Erlina, 2011, p. 10) merupakan kerangka berpikir yang menjelaskan bagaimana cara pandang peneliti terhadap fakta kehidupan sosial dan perlakuan peneliti terhadap ilmu atau teori. Selain itu Paradigma juga menjelaskan bagaimana peneliti memahami suatu masalah, serta kriteria penelitian sebagai landasan untuk menjawab masalah penelitian.

Penelitian ini menggunakan paradigma konstuktivisme. Dimana konstruktivisme merupakan aliran yang menyatakan bahwa realitas itu ada dalam beragam konstruksi mental yang didasarkan pada pengalaman sosial, bersifat lokal, dan spesifik, serta tergantung pada pihak yang melakukannya. Hubungan epistemologis antara pengamat dan objek merupakan satu kesatuan, subjektif dan merupakan hasil perpaduan interaksi di antara keduanya (Salim, 2006, p. 71).

Konstruktivisme bersifat kualitatif dimana tidak lagi meneliti tentang sebab akibat sebuah fenomena, tapi lebih kepada memahami dan merekonstruksi berbagai konstruksi yang sudah ada. Dalam mempelajari dan memahami isu dan fenomena yang diteliti, peneliti dapat memasukan nilai-nilai yang ada pada dirinya. Maka dari itu, paradigma konstruktivisme bersifat subjektif.

Eko dan Bisnis (Riau Economics and Business Reviewe) Volume 10, Nomor 3, 27 September 2019

\section{Objek Penelitian}

Objek penelitian merupakan masalah yang akan diteliti. Objek penelitian menurut Sugiyono (2009, p. 38) adalah suatu sifat dasar dari orang, objek atau kegiatan yang memiliki variasi yang telah ditetapkan oleh peneliti untuk dipelajari kemudian ditarik kesimpulannya. Objek penelitian dalam penelitian ini adalah strategi Riau TV dalam bertahan sebagai televisi lokal di tengah persaingan media.

\section{HASIL}

Riau Televisi (Riau TV) merupakan stasiun televisi lokal pertama di wilayah Riau yang berlokasi di kota Pekanbaru. Riau TV tergabung didalam Stasiun televisi berjaringan JPMC (Jawa Pos Media Corporation), dan mulai mengudara pada tanggal 20 Mei 2001 dengan frekuensi 32 UHF. Seiring waktu dan perkembangannya, Riau TV merubah frekuensi menjadi 46 UHF dengan kekuatan pemancar sebesar $10 \mathrm{Kwatt}$ dan coverage area nya adalah di seluruh kabupaten/kota di Propinsi Riau. Riau TV memiliki izin Prinsip Siaran dengan nomor 394/ KEP/M.KOMINFO/11/2010. (Company Profile PT Riau Media Televisi). Saat ini Riau TV memiliki jam siaran perharinya selama 18 jam, yang dimulai pada pukul 06.00 sampai 24.00 WIB.

Riau TV memilih segmen sebagai TV informasi berkonten lokal. Artinya, Riau TV lebih mengedepankan informasi sebagai segmennya. Informasi tersebut dikemas dalam beragam format. Salah satu program berita unggulan Riau TV yakni Detak Riau yang menginformasikan berita seputar Riau dan sekitarnya.

Sebagai sebuah stasiun televisi lokal di Riau, Riau TV jelas harus bersaing dengan stasiun televisi nasional, dalam memperebutkan jumlah penonton atau pemirsa di wilayah Riau. Televisi nasional jauh lebih unggul dalam hal program siaran maupun program pemberitaan yang ditayangkan, termasuk juga unggul dalam teknologi jaringan tv dengan kualitas visual yang bagus dalam penayangannya

P.ISSN: 1410-7988 E.ISSN: 2614-123X 
(Wahyudi, 2013, p. 8). Untuk itu agar bisa bersaing dengan siaran dari televisi nasional, sebagai televisi lokal Riau Televisi mempauanyai strategi khusus dalam penayangan program acara termasuk untuk sasaran pemasarannya.

Riau televisi lebih menerapkan strategi membuat program dengan mengangkat konten lokal serta kearifan lokal masyarakat Riau pada umumnya. Program acara dengan Konten lokal dan kearifan lokal ini, tidak dimiliki oleh sebagian besar televisi nasional. Kalau pun ada liputan untuk wilayah Riau, durasinya sangat minim dan tidak bisa mengangkat secara keseluruhan konten lokal dan kearifan lokal Riau tersebut. Dari data Riset NIELSEN Project Riau Pos Group Mei - Juni 2016 diperoleh data Faktor masyarakat Riau dalam menentukan pilihan untuk tayangan berita lokal atau berita daerah, lebih tinggi.

Gambar 1. Faktor Menonton TV Lokal dan TV Nasional di Riau

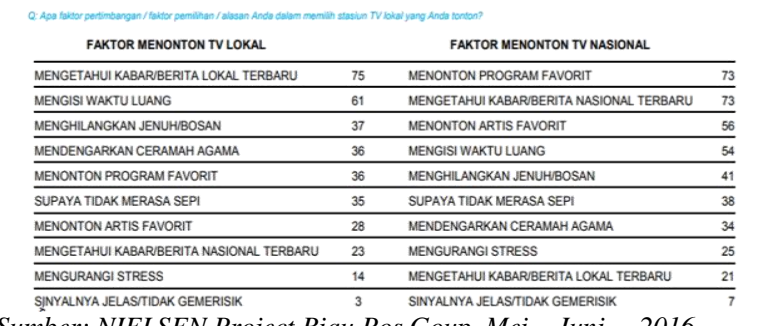

Sumber: NIELSEN Project Riau Pos Goup, Mei-Juni 2016

Berdasarkan data Riset NIELSEN

Project Riau Pos Group Mei - Juni 2016 diperoleh data Fator masyarakat Riau dalam menentukan pilihan untuk tayangan berita lokal atau berita daerah, lebih tinggi. Karena itu stategi marketing Riau TV lebih diarahkan untuk konten lokal, dengan memaksimalkan program Berita Daerah (program Detak Riau), maupun program lainnya yang mengangkat tema kearifan lokal dan konten lokal Riau

Eko dan Bisnis (Riau Economics and Business Reviewe) Volume 10, Nomor 3, 27 September 2019

\section{Gambar 2. Rangking Riau Televisi} (Awareness)

Resensi \& Frekuensi Menonton

\begin{tabular}{|l|l|l|}
\hline \multicolumn{1}{|c|}{ (Ditonton 1 Bulan Terakhir Juni 2016) } \\
\hline No. & TELEVISI & PEMIRSA \\
\hline 1. & ANTV & 122,082 \\
\hline 2. & INDOSIAR & 118,307 \\
\hline 3. & RIAU TELEVISI & 111,638 \\
\hline 4. & SCTV & 108,255 \\
\hline 5. & GLOBAI TV & $\mathbf{8 7 , 4 0 7}$ \\
\hline 6. & RCTI & 86,904 \\
\hline 7. & TRANS 7 & 76,305 \\
\hline 8. & TVRI RIAU & 63,967 \\
\hline 9. & MNC TV & 59,966 \\
\hline 10. & TRANS TV & 55,728 \\
\hline
\end{tabular}

Source: project Riau Pos Group, Mei - Juni 2016

Hasil Riset NIELSEN Project Riau Pos Group Mei - Juni 2016, menunjukkan bahwa Riau TV merupakan TV No. 3 pilihan masyarakat Riau untuk mencari informasi berita terkini untuk wilayah Riau. Tidak hanya program informasi saja, program program pendidikan dan hiburan, yang berangkat dari nilai-nilai lokal Riau menjadi konten program Riau TV juga menarik perhatian pemirsa masyarakat Riau. Riau TV mengudara dengan tagline "Riau televisi : TV-nya orang Riau". Tagline kedaerahaan ini menjadi branding dan terus melekat di hati masyarakat Riau.

Gambar 3. Profil Pemirsa Riau TV (JPM Group)

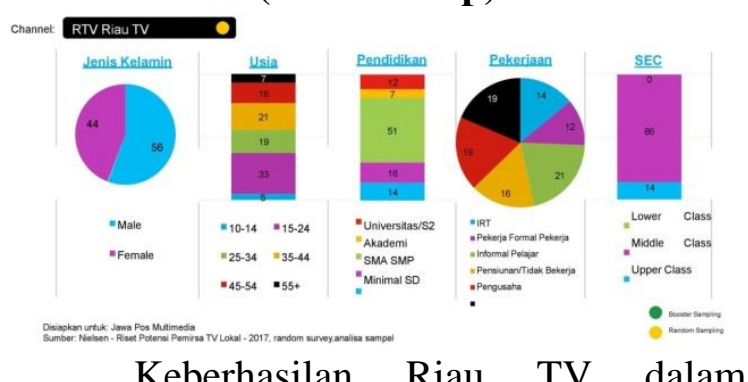

mempertahankan eksistensinya dalam persaingan industri dunia penyiaran hingga saat ini, tentu tidak terlepas dari strategistrategi yang diterapkan. Apalagi bertahan sebagai TV lokal yang diapit oleh keberadaan televisi-televisi swasta yang bersiaran nasional lainnya. Besarnya biaya operasional stasiun televisi, semakin ketatnya persaingan dengan sesama industri 
media, serta sulitnya memperoleh iklan lokal menjadi rintangan terberat Riau TV.

Selain itu, banyaknya masyarakat Riau yang mulai berpindah ke televisi digital, semakin mempersempit jangkauan audien TV lokal yang masih menggunakan sistem analog. Oleh karena itu, para pengelola TV lokal harus berupaya membuat dan menerapkan strategi-strategi yang matang agar mampu menarik minat audien untuk menonton TV lokal serta bagaimana agar terus konsisten menayangkan programprogram dengan konten lokal.

\section{Strategi Riau TV Menghadapi Persaingan dengan TV Nasional dan Eksis sebagai TV Lokal}

Penelitian ini melihat bagaimana strategi Riau TV dalam menghadapi persaingan dengan TV Nasional dan bisa eksis sebagai TV Lokal di wilayah Riau. Pembahasan strategi lebih ditujukan pada strategi yang telah dan sedang dilakukan Riau TV. Bukan strategi yang masih dalam rancangan atau perencanaan.

Berdasarkan teori Ekologi Media Dimmick dan Rohtenbuhler, yang menyatakan untuk bisa mempertahankan eksistensi dan kelangsungan hidupnya, media memerlukan sumber penunjang hidup utama, yaitu : types of content (jenis isi media), types of audien (jenis khalayak sasaran), dan capital (capital/modal yang mencakup modal finansial, dana pemasukan iklan, sumber daya manusia, sarana teknologi dan fasilitas lainnya).

Untuk mengetahui strategi-strategi yang diterapkan Riau TV dalam menghadapi persaingan dengan TV Nasional dan bisa eksis sebagai TV Lokal tersebut, adalah dengan mengetahui bagaimana strategi Riau TV dalam memperoleh ketiga sumber penunjang hidup media untuk bisa tetap bertahan.

\section{Strategi Program TV Berkonten Lokal Merebut Pasar Audien Lokal.}

Haryati menyatakan permasalahan program merupakan salah satu kendala yang dihadapi sebagaian besar televisi lokal. Televisi lokal di daerah hingga saat ini harus

Eko dan Bisnis (Riau Economics and Business Reviewe) Volume 10, Nomor 3, 27 September 2019 berhadapan dengan siaran dari televisi Nasional, yang telah lebih dahulu merebut perhatian pemirsa. (2013, p. 5)

Untuk menghadapi permasalahan ini, Riau TV sebagai TV lokal terus memperkuat eksistensinya dengan strategi memproduksi program siaran yang lebih focus pada program siaran bekonten lokal, baik program pemberitaan maupun program hiburan. Program acara dengan konten lokal dan kearifan lokal ini, tidak dimiliki oleh sebagian besar televisi nasional. Kalau pun ada liputan untuk wilayah Riau, durasinya sangat minim dan tidak bisa mengangkat secara keseluruhan konten lokal dan kearifan lokal Riau tersebut.

Saat ini Riau televisi mempunyai program berkonten lokal andalan, yang didominasi oleh Program-program Pemberitaan atau News, antara lain:

1) Detak Riau Malam (program berita regular) tayang setiap hari pukul 19.00 - 20.00 wib.

2) Detak Riau Siang (program berita regular) tayang Senin - Sabtu pukul 11.00 - 12.00 wib.

3) Detak Melayu (program berita berbahasa daerah - Melayu Riau) tayang Senin - Sabtu pukul 08.00 09.00 wib.

4) Jeruji (program berita kriminalitas) tayang Senin - Jumat pukul 18.30 18.45 wib.

5) Detak Melayu Hangout (program berita melayu turun langsung ke lapangan) tayang setiap Minggu pukul 08.00 - 09.00 wib.

Program pemberitaan (News) dengan konten lokal kota Pekanbaru dan daerah Riau secara umum ini, terus menjadi primadona dan telah mendapat tempat di hati masyarakat Riau. Dengan rating tertinggi, program pemberitaan dan informasi ini, telah menjadi program andalan, baik dari jumlah penonton, serta dari sisi bisnis dengan jumlah pendapatan yang dihasilkan.

Hal ini juga ditegaskan oleh Wakil Pemimpin Redaksi Riau TV Alseptriadi

\footnotetext{
P.ISSN: 1410-7988 E.ISSN: 2614-123X
} 
dalam wawancara pada tanggal 3 Juni 2019 terkait konten lokal yang menjadi andalan bagi program pemberitaan di Riau TV :

"Ya.. memang benar. Kami lebih mengutamakan konten lokal dalam pemberitaan. Sebagai tv lokal, kami sejak dulu terus konsisten untuk mempriotitaskan konten lokal ini dalam pemberitaan yang dibuat. Karena masyarakat penonton Riau $T V$ ingin menyaksikan pemberitaan lokal, apalagi kalau ada berita peristiwa dan kejadian yang terjadi disekitar mereka”.

Selanjutnya dalam wawancara terkait apa strategi-strategi yang dilakukan Riau TV, khususnya dalam hal program berita untuk dapat mempertahankan eksistensinya hingga saat ini? Wakil Pemimpin Redaksi Alseptriadi mengatakan :

"Ya.. seperti yang telah saya sampaikan sebelumnya, salah satu keunggulan kita sebagai TV lokal, kami terus kosisten untuk menghadirkan konten lokal dalam pemberitaan di redaksi Riau TV. dan inilah salah satu strategi kita dalam merebut jumlah pemirsa dan mempertahankan eksistensi. Karena masyarakat di Riau khususnya kota pekanbaru lebih cendrung ingin mengetahui pemberitaan atau permasalahan yang terjadi disekitar mereka. Hal ini bisa kita jadikan tolak ukur, seperti penayangan program berita Detak Riau Malam di jam prime time mulai 19.00 sampai 20.00 WIB. Selama ini rating dari program berita ini cukup tinggi dan banyaknya klien yang meminta untuk pemasangan iklan mereka di program pemberitaan ini. Dan ini bisa kita jadikan rujukan program berita ini banyak ditonton oleh pemirsa".

Seterusnya untuk pertanyaan wawacara apakah program berita tersebut bisa bersaing dengan program program siaran berita yang ada di TV Nasional? Alseptriadi mengungkapkan :

"Ya.. saya rasa bisalah ya.. masalahnya kalau dari penyajian berita kita tidak kalah dari berita TV nasional walaupun lebih mengutamakan konten lokal. Malah kalau ada pemberitaan berupa peristiwa atau kasus, kita bisa tayang lebih

Eko dan Bisnis (Riau Economics and Business Reviewe) Volume 10, Nomor 3, 27 September 2019 dahulu dari berita di TV Nasional. Selain itu kita juga bisa mengulas suatu pemberitaan secara detail dan berkesinambungan dari berbagai narasumber yang kompeten. Jika dibanding TV Nasional, biasanya bagi TV Nasional pemberitaan daerah hanya diulas sekilas tidak bisa secara detail, mungkin terkait durasi pemberitaan mereka juga dengan skala yang lebih luas secara Nasional. Selain itu pemberitaan TV Nasional yang cendrung memberitakan masalah ibukota maupun berita lainnya yang tidak ada sangkut paut dengan daerah Riau, biasanya tidak begitu menarik bagi kebanyak pemirsa di Riau yang lebih kental dengan nuansa Melayu Riau nya".

Untuk menguji jawaban yang diberikan oleh Wakil Pemimpin Redaksi Riau TV Alseptriadi, peneliti melakukan observasi dengan menonton program acara pemberitaan, yang menjadi andalah Riau TV yaitu Detak Riau Malam yang ditayang setiap hari jam 19.00 WIB sampai 20.00 WIB, Detak Riau Siang yang ditayang jam 11.00 WIB sampai 12.00 WIB, serta Detak Melayu yang ditayang jam 08.00 WIB sampai 09.00 WIB, termasuk program berita kriminalitas Jeruji yang ditayang pukul 18.30 WIB sampai 18.45 WIB. Berdasarkan pengamatan yang peneliti lakukan, secara umum memang konten lokal sangat kental dari program pemberitaan Redaksi Riau TV tersebut. Pemberitaan yang diangkat keseluruhannya merupakan peristiwa dan kejadian lokal yang terjadi di wilayah Riau. Bahkan untuk program Detak Melayu, presenter membawakan pemberitaan tersebut dengan bahasa dan logat Melayu Riau.

Konten lokal dalam program pemberitaan Riau TV ini menjadi kekuatan Riau TV untuk bersaing dengan TV Nasional dan mempertahankan eksistensinya. Kebutuhan masyarakat Riau akan informasi-informasi daerah menjadi alasan pemirsa menonton Riau TV, sebagai mana yang diungkapkan Wirdaningsih, S.Sos mengenai program yang menarik di Riau TV :

P.ISSN: 1410-7988 E.ISSN: 2614-123X 
"Program Berita Detak Riau, yaitu program berita seputar masalah yang ada di Riau . Dan sebagai masyarakat Riau saya wajib mengetahui berita terbaru di Riau. Yang mana program ini tidak ada di TV-TV nasional".

Sama halnya dengan yang diungkapkan penonton Riau TV lainnya Rusdiyanto, S.I.Kom, M.I.Kom :

"Program acara yang paling menarik bagi saya yakni program acara berita baik itu program berita khusus criminal maupun program berita biasa, serta program acara yang berisikan konten seni budaya local".

Sementara untuk program siaran hiburan, Riau televisi memilki sejumlah program hiburan yang didominasi program berkonten lokal, antara lain ;

1) Bebual dalam Dendangan (program dialog budaya Melayu Riau diselingi musik melayu) tayang setiap Selasa pukul $12.00-13.00$ wib.

2) Dendang Ocu Kampar (program hiburan daerah masyarakat Kampar - Riau) tayang setiap Selasa pukul $21.00-22.00$ wib

3) Sirawa - Siaran Urang Awak (program hiburan daerah Minangkabau) tayang setiap Rabu pukul 21.00 - 22.00 wib

4) Bursa Niaga (program promo produk dan interaktif langsung dengan pembeli) tayang Senin - Sabtu, 2 kali sehari pukul 10.00 - 11.00 wib dan pukul $15.00-$ 16.00 wib.

5) Jendela Metropolis (program tentang kehidupan masyarakat perkotaan) tayang setiap Sabtu pukul 17.00 - 18.00 wib.

6) Makan Makan (program kuliner lokal) tayang setiap Minggu pukul 11.00 $12.00 \mathrm{wib}$

7) Hilir Mudik bersama Kawasaki (program adventure) tayang setiap Minggu pukul $09.00-10.00$ wib

8) Sinshe Adam (program pengobatan alternative sinshe dari Tiongkok) tayang setiap selasa pukul $20.00-21.00$ wib

9) Dialog Sehat Pak Kobra (program dialog masalah seksualitas dan keharmonisan rumah tangga) tayang setiap Jumat pukul $23.00-24.00 \mathrm{wib}$

Eko dan Bisnis (Riau Economics and Business Reviewe) Volume 10, Nomor 3, 27 September 2019
10) Primaraga Pesona (program senam sehat) tayang setiap hari pukul $06.00-$ $06.30 \mathrm{wib}$

11) Horas Dirantau (program hiburan daerah berbahasa Batak) tayang setiap Selasa pukul $21.00-22.00$ wib

12) Senandung Melayu (program hiburan dengan nuansa Melayu Riau) tayang setiap Senin pukul 21.00 - 22.00 wib.

13) Nada Kenangan (program hiburan dengan lagu kenangan masa lalu) tayang setiap Minggu pukul 21.00 $22.00 \mathrm{wib}$

14) School Up date (program sekolah dengan jurnalis dari para siswa di sekolah) tayang Senin - Jumat pukul $17.00-17.30 \mathrm{wib}$

15) Ni Hao (program hiburan berbahasa Mandarin) tayang setiap Sabtu pukul 21.00-22.00 wib

16) Bilik Probis (program promosi bisnis) tayang Senin - Jumat pukul 18.45 19.00 wib.

Pada wawancara dengan manager Program dan Produksi Riau TV, Khairul Effensi, program siaran di Riau TV dibagi dalam tiga garis besar :

"Saat ini kita memiliki program siaran yang secara garis besar dibagi tiga. Yang pertama program pemberitaan harian atau yang tayang tiap hari seperti Detak Riau Malam, Detak Riau Siang dan Detak Melayu serta program berita kriminalitas Jeruji. Program pemberitaan ini sepenuhnya dikelola oleh Redaksi Riau TV. Seterusnya kita juga mempunyai program dari kerjasama pemerintah daerah, baik dalam bentuk profil daerah, program pembangunan, dialog interaktif dll, sesuai dengan draft kontrak kerjasama antara Riau TV dengan pemerintah Daerah serta pihak terkait. Termasuk program kerjasama dengan pihak swasta. Selanjutnya kita memiliki program hiburan. Disinilah divisi produksi dan program bersama tim kreatif merancang program yang menarik bagi pemirsa. Dari ketiga pembagian program siaran tersebut, program pemberitaan merupakan program yang paling diminati 
dan menjadi primadona oleh pemirsa Riau $T V^{\prime \prime}$.

Program siaran berkonten lokal yang mengangkat kearifan lokal serta bentuk informasi dan berita lokal ini, tidak begitu tersentuh oleh TV Nasional. Hal ini telah membentuk pasar dan segmennya sendiri di hati masyarakat lokal Riau, yang mendapatkannya dari program siaran berkonten lokal yang ditayang oleh Riau TV. Konteks lokalitas dan karakteristik yang berbeda inilah menjadi peluang dan kekuatan Riau TV menghadapi persaingan dengan TV Nasional. Seperti yang diungkapkan Khairul Effendi dalam wawacara terkait apakah program siaran Riau TV lebih memprioritaskan konten dan kearifan budaya lokal?

"Sebenarnya konten lokal itulah yang menjadi kekuatan kami di bagian produksi dan program ini.. saya bersama tim kreatif program, biasanya memang merancang program siaran yang lebih mengangkat budaya lokal Melayu Riau.. namun tentunya dengan sentuhan hal-hal menarik yang lebih mudah dimengerti dan disukai pemirsa. Budaya lokal tersebut dipadukan dengan konsep-konsep modern dan kekinian, namun tetap tidak mengurangi nilai-nilai budaya itu sendiri".

Selanjut saat wawacara dengan pertanyaan strategi apa yang dilakukan Riau TV, khususnya dalam hal program siaran untuk dapat bersaing dengan TV Nasional dan mempertahankan eksistensinya hingga saat ini? Khairul Effendi mengungkapkan :

"Kalau bicara masalah strategi yang dilakukan, kita malah tidak terlalu memikirkan sampai sampai jauh kesitu ya.. kita malah mengalir aja dalam membuat suatu program yang tentunya bisa disukai oleh pemirsa..Tapi intinya program-program yang kita buat tetap mengutamakan konten lokal dan mengangkat kearifan lokal. Kita berusaha untuk berbeda dengan penayangan program-program siaran yang ada di TV nasional. Dan saya rasa program siaran kita bisa bersainglah dengan program siaran TV Nasional. Karena dari pantauan kita saat penayangan program siaran lokal tersebut

Eko dan Bisnis (Riau Economics and Business Reviewe) Volume 10, Nomor 3, 27 September 2019 cukup banyak peminatnya. Hal ini bisa kita ketahui, salah satunya saat ada suatu program budaya seperti Senandung Melayu, banyak pemirsa yang menelpon ketika dibuka link telpon interaktif. Sama halnya dengan program Belacan, juga banyak mendapat respon menarik dari pemirsa. Support dari pemirsa inilah yang membuat kita tetap eksis, sebagai TV lokal di Riau".

Terkait strategi Riau TV dalam menghadapi persaingan dengan TV Nasional dan tetap eksis sebagai TV lokal, dengan lebih mengutamakan dan konsisten untuk memproduksi program siaran berkonten lokal, juga ditegaskan Direktur Operasi Riau TV Sumedi Susato dalam wawancara :

"Yaa.. sejak dari awal pendiriannya Riau TV tetap kosisten untuk memproduksi siaran-siaran berkonten lokal. Termasuk program pemberitaan lokal, yang terus kita maksimalkan...Informasi atau pemberitaan lokal yang kita buat harus bisa segera tersampaikan kemasyarakat Riau. Bahkan tak jarang tim peliputan redaksi juga melakukan live dari lapangan terkait pemberitaan suatu peristiwal kasus atau pun aksi demontrasi massa.. yaa Karena memang segmen lokal inilah yang bisa membuat kita tidak kalah dengan TV nasional, walaupun mereka memiliki banyak program-progaram unggulan. Inilah salah satu strategi kita menghadapi siaran TV nasional. Saya rasa TV nasional yang notabene berbasis di Jakarta, untuk konten lokal, khususnya Melayu Riau tidak akan terlalu menarik bagi mereka. Kecuali mungkin ada hal-hal tertentu yang sengaja mereka turun ke Riau untuk membuata suatu program khusus atau pemberitaan".

Kendati pihak management optimis program Riau TV bisa bersaing dengan TV Nasional, namun sejumlah pemirsa menyorotinya dari sisi lain, perlu adanya pembenahan terlebih dahulu agar bisa bersaing dengan TV Nasional. Seperti yang disampaikan Wirdaningsih dalam wawancara bagaimana tanggapan anda, apakah program siaran Riau TV tersebut

P.ISSN: 1410-7988 E.ISSN: 2614-123X 
bisa bersaing dengan program-program siaran yang ada di TV Nasional? Dan apa kekurangan program siaran Riau TV. Jawabanya :

"Bisa, tetapi Riau TV harus berbenah diri lagi untuk dapat menghasilkan program program yg menghibur dan punya nilai edukasi bagi pemirsanya".

"Menurut saya program Riau TV agak sedikit kaku dan konsepnya masih sederhana. Agak susah jika harus bersaing langsung dengan TV nasional. Saran saya sebaiknya Riau TV mencari satu konsep yg jelas, agar bisa menjadi icon Riau. Salah satu nya dengan membuat program hiburan dan punya nilai edukasi namun tetap mencerminkan tentang nuansa Melayu Riau - nya".

Sama halnya dengan yang disampaikan oleh Rusdianto, terkait tanggapan apakah program siaran Riau TV saat ini bisa bersaing dengan programprogram siaran yang ada di TV Nasional? Dan apa kekurangan program siaran Riau TV:

"Dari penilaian saya beberapa program acara yang saat ini dimiliki oleh Riau TV sudah mampu bersaing dengan program siaran yang ditayangkan oleh $T v$ Nasional, hanya saja tinggal bagaiman tim produksi program untuk dapat memilih topik yang bisa dijadikan isu nasional namun berawal dari persoalan konten lokal".

"Riau TV sebagai Televsi local satu satunya di Propinsi Riau, dalam sebuah program acara yang di produksi oleh tim produksi masih adanya kekurangan akan kekayaan ide serta kurangnya melakukan investigasi untuk mengumpulkan data terkait tema yang akan diangkat, dan sudah saatnya juga management Riau TV untuk melakukan pembinaan sumber daya manusia khususnya pada SDM di bidang Produksi Program”.

Bahkan salah seorang pemirsa Faira Medina Dzikra mengungkapkan program siaran Riau TV belum bisa bersaing dengan program TV Nasional, seperti yang disampaikan dalam wawancara :

"Belum. Perlu ada inovasi dan kreatifitas yang unik dan berbeda dari

Eko dan Bisnis (Riau Economics and Business Reviewe) Volume 10, Nomor 3, 27 September 2019 manajemen Riau TV untuk dapat bersaing dengan TV Nasional".

Dari sejumlah hasil wawancara diatas, peneliti melakukan observasi dengan menonton langsung tayangan programprogram siaran Riau TV. Dari program siaran Riau TV tersebut, ternyata tidak semua menampilan konten lokal Riau. Di jam-jam tertentu Riau TV merelay tayangan dari Jawa Pos TV, khususnya untuk tayangan berita berskala nasional dari program Vice News Tonight jam 06.00 Wib sampai jam 07.00 Wib dan program berita Nusantara Kini Pagi yang ditayang jam 07.00 Wib sampai jam 08.00 Wib. Selain itu juga ada program hiburan Station Dangdut yang ditayang jam $12.00 \mathrm{Wib}$ sampai jam $13.00 \mathrm{Wib}$.

Peneliti membuat suatu analisa, program siaran berkonten lokal saja yang di produksi Riau TV, tidak cukup untuk bisa bersaing dengan program siaran TV Nasional. Diperlukan suatu kreatifitas dan inovasi yang berbeda dengan tayangan program siaran TV Nasional namun tetap lebih mengutamakan konten lokal.

\section{Strategi Memperluas Jaringan Kerjasama Dengan Pemerintah Daerah}

Menjalin kerjasama dengan Pemerintah Daerah Propinsi Riau dan Pemerintah Daerah Kabupaten/Kota di Riau, juga merupakan prioritas Riau TV. Saat ini Riau TV telah menjalin kerjasama dengan 10 pemerintah daerah dari 13 Pemerintah Daerah Propinsi dan Kabupaten/Kota yang ada di Riau, termasuk instansi-instansi pemerintahan di Propinsi Riau. Kerjasama tersebut dikemas melalui iklan layanan masyarakat, advertorial pemberitaan, program siaran profil daerah dan pembangunan daerah, siaran langsung dan siaran tunda suatu kegiatan, serta dialog khusus (talkshow).

Melalui program kerjasama tersebut, pemerintah daerah bisa menyampaikan gagasan dan kebijakankebijakan yang diambil, atau informasi terkait pembangunan daerah, laporan realisasi progres program pembangunan

P.ISSN: 1410-7988 E.ISSN: 2614-123X 
pemerintah daerah, serta berbagai masalah sosial yang terjadi di wilayah Kabupate/Kota dan Propinsi Riau secara umum. Kerjasama dengan pemerintah daerah ini, selain untuk memenuhi informasi masyarakat terkait program pemerintah daerah, juga bisa menjadi sarana penghubung antara pemerintah daerah dengan masyarakat.

Dari sisi anggaran, pendapatan yang dihasilkan bersumber dari kerja sama dengan Pemerintah Daerah melalui iklan layanan masyarakat, profil daerah dan pembangunan daerah, memberikan kontribusi cukup besar, bahkan mencapai lebih dari separoh dari pendapatan Riau TV dalam satu tahun.

Hal ini juga ditegaskan oleh Direktur Operasional Riau TV Sumedi Susanto dalam wawancara pada tanggal 3 Mei 2019 terkait kerjasama Riau TV dengan Pemerintah daerah :

"Menjalin kerjasama dengan
stakehokder pemerintahan daerah
merupakan hal utama yang perlu terus kami pertahankan. Namun tetap dalam kontek untuk saling mendukung.. dimana Riau sebagai sebuah media elektronik akan menyampaikan program kerja dan program pembangunan yang dilakukan pihak pemerintahan. Untuk kerjasama dengan pihak pemerintahan ini.. kita membuat berbagai program, baik itu profil daerah, profil pembangunan daerah, iklan layanan masyarakat, iklan ucapan hari besar, pemberitaan, dialog interaksi live di studio dll".

Selanjutnya pada wawacara dengan pertanyaan apakah kerjasama dengan pemerintah daerah tersebut bisa dibilang salah satu strategi bagi Riau TV untuk eksis sebagai TV Lokal? Sumedi susanto mengungkapkan :

"Ya.. betul karena untuk kerjasama dengan pihak pemerintah daerah ini kita membuat kontrak kerjasama dalam rentang waktu satu tahun anggaran. Berarti dalam satu tahun tersebut kita tinggal menjalankan program yang telah dituliskan dalam kesepakatan kerjasama tersebut. Namun untuk bisa mendapatkan kerjasama pemerintahan tersebut sebelumnya kita harus

Eko dan Bisnis (Riau Economics and Business Reviewe) Volume 10, Nomor 3, 27 September 2019 ikut proses lelang anggaran, seperti layaknya suatu proyek pembangunan yang dilelang sebelum pelaksanaanya. Pihak pemerintah daerah juga sangat ketat dalam menentukan kriteria pemenang lelang yang biasanya masuk dalam program humas atau kominfo untuk promo kegiatan pemerintah. Beruntung Riau TV sebagai TV lokal di Riau sering memenangkan proyek lelang tersebut. Dan hampir setiap tahunnya kita memiliki kontrak kerjasama dengan pemerintah daerah ini, baik pemerintah daerah propinsi Riau, maupun pemerintah daerah kabupaten/kota di Riau”.

Bahkan saat ditanya Sumber-sumber pendapatan Riau TV saat ini dari mana saja? Sumedi Susanto mengakui lebih dari separohnya berasal dari kerjasama dengan pihak pemerintah daerah :

"Untuk sumber pendapatan Riau TV memang diakui lebih dari separonnya berasal dari kerjsama dengan pihak pemerintah daerah. Sementara dari sektor swasta atau komersial masih sering terjadi fluktuatif.. suatu saat pada moment-moment tertentu, iklan dari sektor swasta ini banyak, namun dilain waktu malah terjadi penurunan".

\section{Gambar 4. Proyeksi dan Realisasi Pendapatan Riau TV dari Kerjasama Pemerintah Daerah 2018}

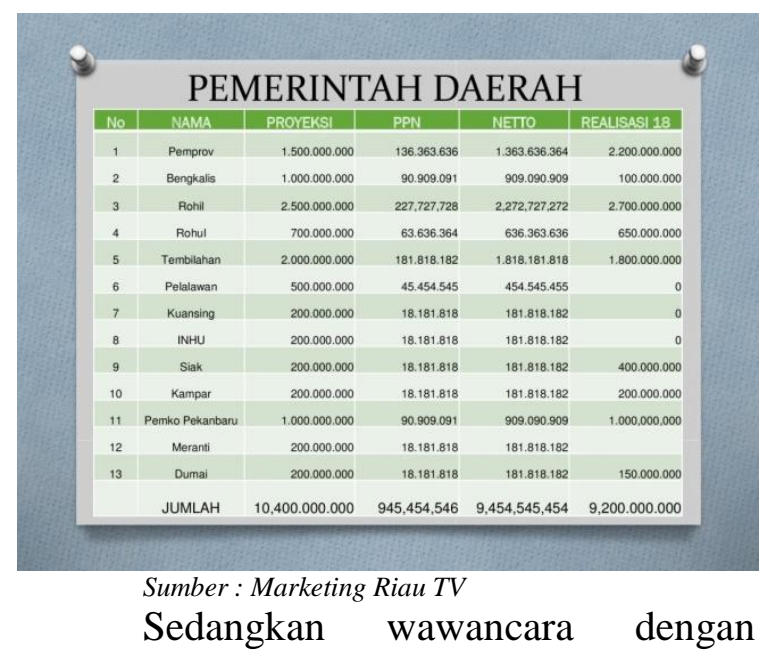
Senior Manager Marketing Riau TV Tri Hirda Putri terkait pertanyaan pendapatan Riau TV berasal dari mana saja? Diungkapkan :

P.ISSN: 1410-7988 E.ISSN: 2614-123X 
"Setidaknya ada tiga sumber pendapatan Riau TV, antara lain dari Redaksi dan pemberitaan melalui berita advertorial kerjasama baik dari pemerintahan maupun pihak swasta. Yang kedua berasal dari kontrak kerjasama dengan pemerintah daerah dan sejumlah instansi terkait. Seterusnya berasal dari sektor swasta, dalam bentuk pemasangan iklan atau sponsorship program siaran".

Selanjutkan untuk pertanyaan berapa target Pendapatan Riau TV pertahunnya? Tri Hirda Putri menanggapi :

"Untuk tahun 2018 lalu kita menargetkan pendapatan hingga 30 Milyar Rupiah. Dan Alhamdulillah bisa terealisasi sekitar 26 Milyar Rupiah, walaupun tidak mencapai target yang kita tetapkan sebelumnya. Dan untuk tahun 2019 ini kita kembali menargetkan 30 Milyar Rupiah".

Gambar 5. Proyeksi Pendapatan Riau TV Tahun 2019

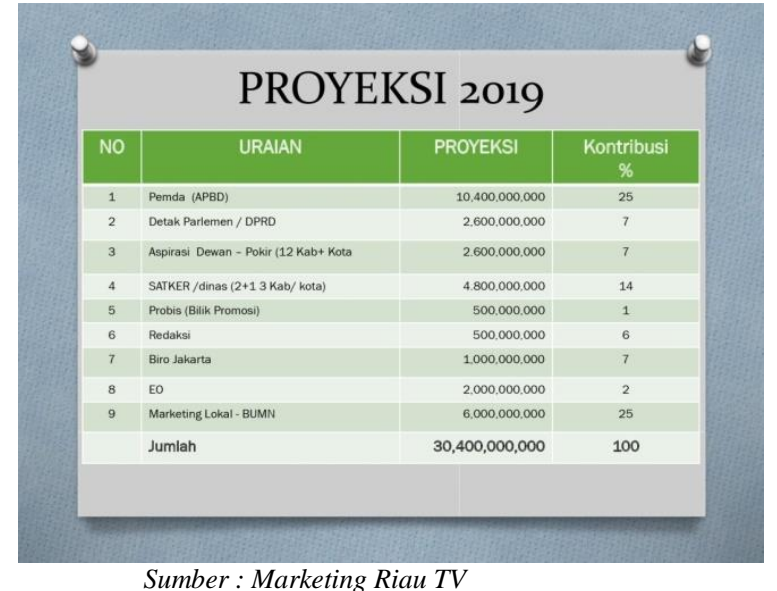

\section{Strategi MemamfaatkanTeknologi Internet}

Pesatnya kemajuan Ilmu dan Teknologi di era globalisasi ini, khususnya teknologi informasi saat ini, juga menjadi prioritas bagi Riau TV. Perkembangan teknologi tersebut dimanfaatkan oleh Riau TV untuk melakukan konvergensi media dengan membuat tayangan live steraming program siaran Riau TV melalui internet. Live streaming ini dapat diakses melalui situs website Riau TV, www.riautelevisi.com yang tersedia dalam bentuk aplikasi android, apple, windows dan youtube.

Tujuan utama pembuatan tayangan live streaming siaran Riau TV ini adalah agar Eko dan Bisnis (Riau Economics and Business Reviewe) Volume 10, Nomor 3, 27 September 2019 pemirsa dapat menikmati tayangan program Riau TV dimana saja dan kapan saja, di seluruh wilayah Indonesia bahkan di luar negeri melalui akses internet. Pemirsa bisa mengakses secara langsung berbagai informasi pemberitaan seputar Riau yang ditayangkan dalam program pemberitaan Riau TV, termasuk juga program hiburan yang diproduksi Riau TV.

Dalam wawancara dengan Direktur Operasional Riau TV Sumedi Susanto terkait kemajuan Teknologi Digital, khususnya dibidang teknologi pertelevisian saat ini, apakah Riau TV juga melakukan pemamfaatan teknologi digital tersebut? Sumedi Susanto mengungkapkan :

"Kemajuan teknologi digital sekarang ini jelas tak bisa dihindari, begitu juga kami di Riau TV. Kendati hanya sebuah stasiun TV Lokal di Riau, kita tetap harus up date teknologi. Setidaknya saat ini siaran Riau TV sudah bisa diakses melalui media internet seperti TV streaming. Selain itu kita juga memamfaatkan media sosial yang saat ini banyak digandrungi masyarakat, seperti facebook, twitter, dan youtube untuk mengupload program siaran kita, khususnya pemberitaan. Riau TV juga bergabung dengan aplikasi Kugo dan JPM milik JawaPos group untuk bisa diakses langsung dari smartphone. Seterusnya dalam dua tahun terakhir Riau TV juga menjajaki penggunaan satelit bekerjasama dengan NinMedia dan Jaringan TV kabel. Pemamfaatan teknologi digital ini dengan tujuan agar Riau TV bisa diakses langsung oleh pemirsa dimana saja, asalkan ada jaringan internet, tanpa harus menonton tv dirumah. Kondisi ini juga untuk melepaskan Riau TV dari bayang-bayang coverage area TV lokal yang selama ini hanya bisa ditonton diwilayah Riau. Selain itu bagi klien pemasang iklan dan mitra kerjasama, hal ini juga menguntungkan, karena dengan harga lokal, pemasaran produk mereka bisa menembus ke lokasi dimana masyarakat menyaksikan Riau TV diluar wilayah Riau”.

Disisi lain pemamfaatan teknologi digital ini juga menjadi prioritas bagi divisi

P.ISSN: 1410-7988 E.ISSN: 2614-123X 
pemberitaan atau redaksi Riau TV. Wakil Pemimpin Redaksi Riau TV Alseptriadi dalam wawancara terkait kemajuan Teknologi Digital khususnya dibidang teknologi pertelevisian saat ini, apakah Program berita Riau TV juga melakukan pemamfaatan teknologi digital tersebut? Alseptriadi menyampaikan :

"Ya sudah pasti.. karena kalau kita tidak memamfaat teknologi digital alamat akan karam kapal Riau TV ini.. hehehehehe... pemberitaan yang kami buat langsung di upload melalui internet, baik itu website maupun media sosial. Untuk upload website kami menggunakan situs www.riautelevisi.com yang merupakan situs resmi dari Riau TV. sementara untuk upload di media sosial, redaksi Riau TV juga memiliki jejaring sosial seperti facebook, twitter dan youtube sendiri yang dibuat khusus untuk mengupload berita-berita yang sebelumnya telah ditayang di Studio Riau TV. Pengikut jejaring sosial redaksi Riau TV ini juga cukup banyak mencapai ribuan orang. Sasaran kita mengupload pemberitaan tersebut untuk memberikan akses bagi pemirsa Riau TV yang mungkin sebelumnya tidak bisa menonton tayangan pemberitaan yang kita tayangkan. Tapi tak jarang juga pemberitaan kita dibagikan disejumlah media sosial facebook, youtube maupun ke whatsApp group. Selain itu agar pemberitaan tersebut bisa diakses oleh orang-orang di luar Riau, karena sebagai TV lokal, Riau TV memiliki keterbatasan dalam area penyiaraannya".

Tujuan lain dari tayangan live streaming Riau TV ini adalah untuk memudahkan Riau TV memasarkan produk siarannya, dalam mencari pemasang iklan dan mitra kerjasama. Sebelumnya Riau TV lebih mengandalkan pemasang iklan dan mitra kerjasama dengan branding lokal Riau, namun dengan keberadaan live streaming ini bisa menjangkau pemasangan iklan dan mitra kerjasama serta sponsorship dari luar wilayah Riau (branding Nasional). Dari live streaming ini, para pemasangan iklan bisa memantau langsung tayangan iklan mereka serta program-program siaran yang disiarkan

Eko dan Bisnis (Riau Economics and Business Reviewe) Volume 10, Nomor 3, 27 September 2019
Riau TV. Dampak keberadaan live streaming ini cukup positif bagi pendapatan Riau TV, dengan adanya sejumlah iklan branding Nasional, seperti produk Sarimi, Bimoli, Rinnai serta produk otomotif Kawasaki dan Suzuki yang ditayang di Riau TV. Seperti yang disampaikan Senior Manager Marketing Riau TV Tri Hirda Putri dari hasil wawancara berikut ini :

"Media digital sekarang ini memang sangat berperan dalam mempromosikan program siaran Riau TV. Karena itu kami di divisi marketing juga sangat terbantu dalam memasarkan dan menawarkan iklan kepada klien. Apalagi sekarang ini program siaran Riau TV sudah bisa diakses melalui tv streaming, yang tentunya dengan jangkauan siaran yang lebih luas, akan menambah nilai plus bagi Riau TV. Dalam menawarkan pemasangan iklan kepada klien, kami bisa mengakses secara langsung streaming Riau TV tersebut, dan memperlihatkannya kepada calon klien. Dan itu akan mempermudah pekerjaan kami untuk bernegosiasi dengan calon klien".

Keberadaan Riau TV dengan memamfaatkan teknologi digital juga mendapat respon yang cukup baik dari pemirsa Riau TV. Berdasarkan hasil wawancara dengan pemirsa rata-rata menyampaikan bisa menyaksikan tayangan Riau TV melalui TV streaming, seperti yang disampaikan Wirdaningsih S.Sos berikut ini :

"Ya bisa... Biasanya saya di saat jam tertentu khususnya untuk Program Berita, jika saya tidak berada di depan televisi, saya menyaksikan tayangan Riau $T V$ melalui $T V$ streaming Riau TV, menggunakan smartphone".

Sama halnya seperti yang diungkapkan pemirsa lainnya, Faira Medina Dzikra, kendati bisa menyaksikan tayangan Riau TV melalui TV streaming, namun kadangkala tayangannya mengalami ganggguan :

"Bisa... Namun terkadang mengalami gangguan. Seperti disaat turunnya hujan dan petir. Bahkan siaran

P.ISSN: 1410-7988 E.ISSN: 2614-123X 
Riau TV juga tidak dapat sama sekali ditonton".

Dari pemaparan diatas peneliti mencoba menyaksikan dan mengamati tayangan Riau TV, melalui TV streaming dari website www.riautelevisi.com, aplikasi Kugo dan aplikasi JPM Streaming. Dari pengamatan tersebut peneliti bisa menarik kesimpulan bahwa TV streaming Riau TV, baik di website maupun aplikasi, tayangannya cukup bagus dengan kualitas gambar HD. Namun untuk TV streaming Riau TV di website, tayanganya masih dalam format $3: 4$ atau format TV lama, belum format $9: 16$ seperti kebanyakan fotmat tayangan tv saat ini.

\section{Strategi Menggelar Kegiatan Off Air dan moment-moment Khusus}

Strategi Riau TV untuk lebih mendekatkan diri kepada pemirsa secara langsung, Riau TV rutin menggelar kegiatan atau event-event off air. Program off air ini dilakukan diluar ruang studio (out door) yang bertujuan untuk menarik minat penonton sekaligus meningkatkan awareness masyarakat terhadap Riau TV. Kegiatan ini dilakukan dengan melibatkan langsung penonton dan masyarakat umumnya,sehingga bisa tercipta interaksi dan kedekatan mereka dengan Riau TV.

Event-event off air Riau TV ini dikemas dalam bentuk kegiatan yang melibatkan masyarakat banyak, seperti jalan santai, senam massal Riau Sehat, Fun Bike, berbagai perlombaan mulai dari tingkat Taman Kanak-kanak hingga tinggal Mahasiswa. Dalam hal pendanaan untuk kegiatan off air tersebut, Riau TV menjalin kerjasama dengan mitra dan sponshorship dari perusahaan serta produk.

Selain itu Riau TV juga melakukan raodshow ke sekolah dan kampus, dengan membuat program khusus pendidikan, termasuk berbagai perlombaan di bidang pertelevisian yang akan diikuti oleh para pelajar dan mahasiswa. Kegiatan roadshow ke sekolah dan kampus ini, sekalian mempromosikan Riau TV dikalangan generasi muda termasuk generasi milenial. Pangsa pasar generasi muda ini harus diraih,

Eko dan Bisnis (Riau Economics and Business Reviewe) Volume 10, Nomor 3, 27 September 2019 untuk kelangsungan jumlah penonton Riau TV kedepannya.

Event-event off air Riau TV ini juga dilakukan di moment-moment khusus, seperti HUT Riau TV, HUT Propinsi Riau, perayaan Hari Kemerdekaan, dll. Untuk pelaksanaan kegiatan off air ini Riau TV secara khusus juga membentuk suatu divisi yaitu Event Organizer.

Dalam wawancara terkait apakah Riau TV juga melakukan program off air yang tujuannya juga untuk menarik pemasang iklan dengan sponsorhip suatu kegiatan? Senior Manager Marketing Riau TV Tri Hirda Putri menyampaikan :

"Memang kegiatan off air ini telah menjadi agenda rutin Riau TV khususnya pada moment-moment khusus, seperti HUT Riau TV setiap tanggal $20 \mathrm{Mei}$. Selain itu juga pada moment-moment peringatan HUT kota Pekanbaru di bulan Juni, HUT Riau dan Hari Kemerdekaan di bulan Agustus serta Sumpah Pemuda dibulan Oktober. Biasanya untuk menggelar kegiatan off air ini kita langsung menawarkan sponsorship dari suatu produk, baik itu produk makanan, minuman kesehatan, obat-obatan dll, termasuk juga pemerintah daerah dan sejumlah instansi. Jenis kegiatannya juga cukup banyak, seperti jalan santai, senam massal Riau Sehat, Fun bike, panggung hiburan, lomba kreasi anak-anak maupun remaja. Biasanya untuk event off air ini melibatkan masyarakat banyak yang ikut serta meramaikannya. Respon masyarakat biasanya juga cukup positif, apalagi dalam event off air tersebut juga dibagikan berbagai macam hadiah menarik dengan sistem undian kupon peserta. Hadiahnya mulai dari sepeda motor, kulkas, rice cooker, dispenser, strika, kipas angin, sampai voucer hotel, dll. Diawal tahun ajaran baru, Riau TV juga membuat program khusus pendidikan, dengan melakukan raodshow ke sekolah dan kampus di Riau. Pada Road show ini juga digelar berbagai perlombaan di bidang pertelevisian yang akan diikuti oleh para pelajar dan mahasiswa. Kegiatan roadshow

P.ISSN: 1410-7988 E.ISSN: 2614-123X 
ke sekolah dan kampus ini, sekalian mempromosikan Riau TV dikalangan generasi muda termasuk generasi milenial. Pangsa pasar generasi muda ini harus diraih, untuk kelangsungan jumlah penonton Riau TV kedepannya".

Bagi pemirsa Riau TV, event-event off air yang dilakukan Riau TV juga mendapat respon cukup positif. Event-event tersebut dinilai bisa mendekatkan Riau TV dengan pemirsanya. Seperti yang disampaikan Wirdaningsih dalam wawancara apakah event-event tersebut lebih mendekatkan Riau TV dengan pemirsanya?

"Ya, saya rasa bisa. Karna Riau TV bisa mensosialisasikan program-program acaranya kepada masyarakat Riau. Karena menurut saya, tidak semua pemirsa mengetahui program-program acara yang ada di Riau TV. Dan evevt-event (off air) itu adalah salah satu cara untuk mensosialisakannya".

Sementara dalam wawancara dengan pemirsa Riau TV yang berada di luar kota Pekanbaru, tepatnya di kota Bangkinang Kabupaten Kampar, pemirsa Riau TV Rusdiyanto mengungkapkan :

"Dalam penilaian saya kegiatan event off air yang dilaksanakan oleh Riau TV khususnya di wilayah Kabupaten Kampar sangat membuat adanya kedekatan antara audien dengan Riau TV sendiri sebagai stasiun televisi lokal yang ada di Riau, dan ini juga menimbulkan sebuah partisipasi aktif masyarakat dalam membangun kemitraan antara masyarakat dan Riau TV'.

\section{Kendala dan Hambatan yang dialami Riau TV}

Kendati berbagai strategi yang dipaparkan telah dilakukan secara optimal, namun Riau TV tetap masih memiliki sejumlah kendala dan hambatan dalam bersaing dengan TV Nasional dan tetap eksis sebagai TV Lokal. Berbagai kendala dan hambatan tersebut antara lain :

\section{Terbatasnya peralatan pertelevisian Riau TV}

Terbatasnya peralatan yang dimiliki, baik itu kamera, sound system, komputer editing, termasuk sejumlah peralatan yang

Eko dan Bisnis (Riau Economics and Business Reviewe) Volume 10, Nomor 3, 27 September 2019 dibutuhkan untuk hunting di lapangan saat produksi program-program siaran, membuat siaran yang produksi Riau TV tidak maksimal. Minimnya peralatan ini memang masih menjadi kendala Riau TV dalam memproduksi program, karena tidak bisa memproduksi suatu siaran yang membutuhkan peralatan televisi yang lengkap, khususnya program siaran di luar studio atau lapangan. Sebagai TV lokal dengan permodalan yang masih terbatas, Riau TV masih kesulitan untuk melakukan pembaruan atau pengembangan peralatan pertelevisian, yang membutuhkan biaya sangat besar. Terkait permasalahan ini, Direktur Operasional Riau TV Sumedi Susanto, dalam wawancara kendala-kendala dan hambatan yang dihadapi Riau TV dalam mempertahankan eksistensinya sebagai TV Lokal, mengakui :

"Kendala terbesar yang dihadapi Riau TV adalah masalah pengembangan perusahaan dan alih teknologi. Karena hal ini membutuhkan modal yang cukup besar. Apalagi kemajuan teknologi khususnya di bidang pertelevisian yang cukup pesat, masih belum bisa diikuti oleh Riau TV secara optimal.. karena ya itu tadi.. membutuhkan biaya yang sangat besar, sementara kemampuan Riau TV untuk memenuhi hal tersebut masih terbatas. Namun walau bagaimana pun, mau tidak mau tuntutan kemajuan teknologi tersebut, tetap harus dipenuhi kendati harus dilakukan secara bertahap dan dengan skala prioritas. Saat ini standar peralatan siaran, baik di Studio maupun untuk pembuatan program siaran dilapangan juga masih dibawah standar broachash Stasiun Televisi. Termasuk juga masalah SDM yang juga masih perlu dilakukan berbagai pembenahan dan pelatihan. Dan kami tetap yakin kedepan Riau TV masih bisa tetap eksis sebagai TV lokal, khususnya di wilayah Riau”.

Hal yang sama terkait kendala dan hambatan yang dihadapi Riau TV, juga disampaikan Manager Produksi dan Program Riau TV, Khairul Effendi :

P.ISSN: 1410-7988 E.ISSN: 2614-123X 
"Kendala kita ya masih terkait dengan peralatan yang ada saat ini. Baik peralatan kamera, ligthing, sound untuk pengambilan visual dilapangan. Termasuk peralatan komputer editing program untuk pengolahan hasil visual, menjadi sebuah program siaran. Peralatan yang ada Itu masih kurang dan tidak bisa maksimal untuk menghasilkan produksi program siaran yang bagus. Namun hal-hal tersebut masih bisa kita tutupi dengan kreatifitas SDM yang ada saat ini di divisi program".

\section{Kemajuan tehnologi pertelevisian belum bisa diikuti oleh Riau TV}

Kemajuan tehnologi pertelevisian saat ini dengan perkembangan teknologi peralatan televisi yang semakin canggih, belum bisa diikuti oleh televisi lokal termasuk Riau TV. Apalagi peralatan dengan teknologi canggih tersebut, harganya sangat mahal. Untuk up date teknologi tersebut akan membutuhkan anggaran yang juga sangat besar.

Dari sisi kualitas tayangan Riau TV, tampilan fisiknya masih kurang menarik dibanding TV Nasional. Visual yang cenderung gelap dan warna yang kurang cerah, serta kualitas video yang masih rendah, dibanding dengan tayangan TV Nasional dengan kualitas tayangan yang jauh lebih jernih dengan menggunakan teknologi pertelevisian yang lebih maju. Masalah ini juga diakui Senior Manager Marketing Riau TV, Tri Hirda Putri. Dalam wawancara terkait apa kendala dan hambatan yang dihadapi oleh marketing Riau TV dalam mendapatkan pemasukan iklan :

"Kalau kendala yang kita hadapi masih seputar permasalahan teknis ya. ya mungkin karena jaringan internet atau ada gangguan pemancar dan lainnya, Riau TV tidak bisa diakses oleh masyarakat. Dan hal ini tentukan akan membuat pemasang iklan juga merasa dirugikan. Karena biasanya kalau mereka memiliki kontrak selama satu bulan berarti iklan mereka harus tayang selama full satu bulan. Dan tidak bisa dipotong sesuai kontraknya, namun solusinya biasanya ditambah atau diganti hari penayangannya. Selain itu kualitas siaran kita juga masih rendah dibanding TV

Eko dan Bisnis (Riau Economics and Business Reviewe) Volume 10, Nomor 3, 27 September 2019
Nasional, dan ini juga menjadi kendala tersendiri".

Dari divisi pemberitaan atau Redaksi masalah teknis ini, khususnya masalah peralatan, juga menjadi kendala dan hambatan, seperti yang diungkapkan Wakil Pemimpin Redaksi Riau TV Alseptriadi :

"Secara tekhnis kita masih banyak kekurangan, khususnya masalah peralatan yang digunakan dalam peliputan pemberitaan maupun saat pengeditan hasil liputan menjadi sebuah pemberitaan. Tidak semua kameraman di lapangan menggunakan standar kamera peliputan, bahkan beberapa diantaranya hanya menggunakan handycam. Untuk pengeditan hasil liputan pun kita juga masih belum bisa optimal, karena program editing yang kita gunakan, kalau bisa dibilang sudah jadul. Sementara untuk SDM sendiri kita masih bisa handalkan karena mereka sudah cukup lama berkecimpung didunia pertelevisian yang rata-rata telah diatas 5 tahun".

\section{SDM dan tenaga ahli Riau TV masih terbatas}

Dari sisi SDM sendiri, Riau televisi memiliki SDM dan tenaga ahli yang masih terbatas, khususnya dalam hal penguasaan ilmu dan teknologi pertelevisian. Kualitas SDM yang dimiliki Riau TV perlu terus diasah dan ditingkatkan skill serta kemampuannya, dengan diberi pelatihanpelatihan sehingga bisa menyesuaikan dengan perkembangan zaman dan kemajuan ilmu dan teknologi, terutama dibidang televisi.

\section{SIMPULAN}

Dari hasil penelitian dan pembahasan yang dilakukan, dapat dibuat kesimpulan bahwa untuk bisa bersaing dengan TV Nasional dan tetap eksis sebagai TV Lokal, Riau TV membuat sejumlah strategi. Strategi yang dilakukan Riau TV mengacu pada bagaimana Riau TV dalam meraih tiga sumber kehidupannya sebagai media yaitu content (program siaran), audien (pemirsa) dan capital (modal).

\footnotetext{
P.ISSN: 1410-7988 E.ISSN: 2614-123X
} 
Strategi-strategi yang dilakukan Riau TV antara lain : (1) Strategi Program TV Berkonten Lokal Merebut Pasar Audien Lokal, (2) Strategi Memperluas Jaringan Kerjasama Dengan Pemerintah Daerah, (3) Strategi Memamfaatkan Teknologi Internet, dan (4) Strategi Menggelar Kegiatan Off Air dan moment-moment Khusus.

Dari strategi-strategi tersebut, Riau TV tetap mampu bertahan selama 18 tahun terakhir, sejak berdiri tahun 2001 sebagai TV lokal, ditengah gempuran program siaran TV Nasional. Khususnya untuk strategi Memperluas Jaringan Kerjasama dengan Pemerintah Daerah. Riau TV terus menjalin kerjasama dengan pemerintah daerah ini, termasuk instansi-instansi pemerintahan di Propinsi Riau.

Dari sisi anggaran, pendapatan yang dihasilkan bersumber dari kerja sama dengan Pemerintah Daerah melalui iklan layanan masyarakat, profil daerah dan pembangunan daerah, dan lain-lain, memberikan kontribusi cukup besar, bahkan mencapai lebih dari separoh dari pendapatan Riau TV dalam satu tahun.

Kendati berbagai strategi yang dipaparkan telah dilakukan secara optimal, namun Riau TV tetap masih memiliki sejumlah kendala dan hambatan dalam bersaing dengan TV Nasional dan tetap eksis sebagai TV Lokal. Berbagai kendala dan hambatan tersebut antara lain : (1) Terbatasnya peralatan pertelevisian Riau TV, (2) Kemajuan tehnologi pertelevisian belum bisa diikuti oleh Riau TV, dan (3) SDM dan tenaga ahli Riau TV masih terbatas.

\section{DAFTAR RUJUKAN}

\section{Buku :}

Djamal, Hidajayanto \& Fachruddin, Andi. (2011). Dasar-Dasar Penyiaran: Sejarah, Organisasi, operasional, dan Regulasi. Jakarta : Kencana

Downing, John. (2004). The Handbook of Media Studies. London: Sage Publication.

Dimmick, J.,\& Rothenbuhler, E. (1984). Competitive displacement in the communication industries: New media

Eko dan Bisnis (Riau Economics and Business Reviewe) Volume 10, Nomor 3, 27 September 2019 in old environments. In R. E. Rice (Ed.), The New Media: Communication, Research, and Technology. Beverly Hills, CA: Sage. Erlina. (2011). Metodologi Penelitian. Medan: USU Press.

George, R, Terry, \& Leslie W. Rue. (2003). Dasar-dasar Manajemen. Jakarta: PT. Bumi Aksara.

Ibrahim, I.S. (2006). Media Alternatif: Giving Voices to the Voiceless. In: A. Alfathri. (ed). Resistensi Gaya Hidup: Teori dan Realitas. Yogyakarta: Jalasutra.

Kyker, Keith. \& Christopher, C. (2004). Television Production: A Classroom Approach, Second Edition. USA: Greenwood Publishing Group.

Krisyantono, Rachmat. (2007). Tekhnik Praktis Riset Komunikasi (Disertasi Contoh Riset Praktis Media, Public Relation, Advertising, Komunikasi Organisasi, Komunikasi Pemasaran). Jakarta. Kencana Media Group.

Morissan. (2005). Jurnalistik Televisi Mutakhir. Tangerang: Ramdina Prakarsa.

Morissan. (2008). Manajemen Media Penyiaran: Strategi Mengelola Radio dan Televisi. Jakarta: Prenada Media Group.

McQuail, Denis. (2011). Teori Komunikasi Massa, Edisi 6. Jakarta: Salemba Humanika

Moloeng, Lexy J. (2007). Metodologi penelitian Kualitatif, Edisi Revisi. Bandung: PT. Remaja Rosdakarya

Moloeng, Lexy J. (2002). Metodologi penelitian Kualitatif. Bandung: PT. Remaja Rosdakarya

Salim, Agus. (2006). Teori dan Paradigma Penelitian Sosial. Yogyakarta: Tiara Wacana.

Sugiyono. (2011). Metode Penelitian Kuantitatif Kualitatif dan $R \& D$. Bandung : Alfabeta

Sucipto, Toto. (1998). Peranan Media Massa Lokal Bagi Pembangunan danPengembangan Kebudayaan Daerah. Bandung : CV Kidang Emas

P.ISSN: 1410-7988 E.ISSN: 2614-123X 
Tebba, Sudirman. (2005). Jurnalistik Baru; History of journalism in Indonesia, theory, and practice of journalistic reporting. Kalam Indonesia.

Utud, Yusiatie. \& Latief, Rusman. (2015). Siaran Televisi Non Drama : Kreatif, Produksi, Public Relations, dan Iklan. Jakarta: Prenadamedia Group

Wahyudi, J.B. (1996). Dasar-Dasar Jurnalistik Radio dan Televisi. Jakarta: Pustaka Utama Grafiti.

Wahyudi, S.M. (2013). Televisi Lokal : Strategi Jitu Memenangkan Persaingan \& Merebut Pemirsa TV. Madura : UTM Press.

\section{Artikel :}

Agung Prabowo. (2012). Era Penyiaran Digital : Pengembangan atau Pemberangusan TV Lokal dan TV Komunitas?. UPN Veteran Yogyakarta. Jurnal Komunikasi, Volume 1, Nomor 4, Januari 2012

Herawati, F. Anita \& Budi, Setio HH. (2007). Ekologi Media Radio Siaran di Yogyakarta: Kajian Teori Niche terhadap Program Acara Radio Siaran di Propinsi Daerah Istimewa Yogyakarta. Jurnal Ilmu Komunikasi Volume 4, Nomor 2, Desember 2007.

Haryati. (2013). Televisi Lokal Dalam Representasi Identitas Budaya. Observasi Balai Pengkajian dan Pengembangan Komunikasi dan Informatika (BPPKI) Bandung. SSN. 1412 - 5900 Vol. 11, Nomor 1, Tahun 2013.

Prasetiya, L. 2011. Kompetisi Surat Kabar Lokal Yogyakarta Berdasarkan Tingkat Kepuasan Biro Iklan Pada Layanan Jasa Mediasurat Kabar. FISIP Universitas Atma Jaya Yogyakarta. www.eJournal.Uajy.Ac.Id/1481/1/0ko m02720.

Rinowati, N.A. (2011). Eksistensi Televisi Lokal (Studi Kasus: Eksistensi TVKU dalam Kompetisi Industri Penyiaran). Universitas Diponegoro.
Sari, Pingkan Earliana \& Pramonojati, T.A., S.Sos., M.Ds. (2019). Strategi Program Acara Hitam Putih Dalam Mempertahankan Eksistensi Program Di Stasiun Televisi Trans7. Program Studi S1 Ilmu Komunikasi, Fakultas Komunikasi dan Bisnis, Universitas Telkom. E-Proceeding of Management, Vol. 6, No. 1, April 2019.

Sumiaty, Noneng. (2015). Konstruksi Realitas Siaran Berita Pada Televisi Lokal. Balai Pengkajian dan Pengembangan Komunikasi dan Informatika (BPPKI) Bandung

Yuyun, W.I. Surya. (2006). The Construction of Cultural Identity in Local Television Station's. Programs in Indonesia. Department of Communication Science., Faculty of Social and Political Sciences, Airlangga University.

Website, Riset, dll :

ATLVI. (2008). Televisi Lokal Sebagai Jawaban Otonomi Daerah. http://www.atvli.com/index.php/home /detil_berita/53.

NIELSEN. (2016) Project Riau Pos Goup, Mei-Juni 2016

NIELSEN. (2017) Riset Potensi Pemirsa TV Lokal, Jawa Pos Multi Media 2017, random survey, analisa sampel PT Riau Media Televisi : Company Profile Website Riau TV. http://www.riautelevisi.com/program. $\underline{h t m}$

Undang-Undang Republik Indonesia Nomor : 32 Tahun 2002 Tentang Penyiaran

Peraturan Menteri Komunikasi dan Informasi No 43/PER/M.KOMINFO/10/2009 